\title{
Transcriptional dysregulation of 5-HT1A autoreceptors in mental illness
}

\author{
Paul R Albert", Brice Le François and Anne M Millar
}

\begin{abstract}
The serotonin-1A (5-HT1A) receptor is among the most abundant and widely distributed 5-HT receptors in the brain, but is also expressed on serotonin neurons as an autoreceptor where it plays a critical role in regulating the activity of the entire serotonin system. Over-expression of the 5-HT1A autoreceptor has been implicated in reducing serotonergic neurotransmission, and is associated with major depression and suicide. Extensive characterization of the transcriptional regulation of the 5-HT1A gene (HTR1A) using cell culture systems has revealed a GC-rich "housekeeping" promoter that non-selectively drives its expression; this is flanked by a series of upstream repressor elements for REST, Freud-1/CC2D1A and Freud-2/CC2D1B factors that not only restrict its expression to neurons, but may also regulate the level of expression of 5-HT1A receptors in various subsets of neurons, including serotonergic neurons. A separate set of allele-specific factors, including Deaf1, Hes 1 and Hes5 repress at the HTR1A C(-1019)G (rs6295) polymorphism in serotonergic neurons in culture, as well as in vivo. Pet1, an obligatory enhancer for serotonergic differentiation, has been identified as a potent activator of 5-HT1A autoreceptor expression. Taken together, these results highlight an integrated regulation of 5-HT1A autoreceptors that differs in several aspects from regulation of post-synaptic 5-HT1A receptors, and could be selectively targeted to enhance serotonergic neurotransmission.
\end{abstract}

\section{Serotonin in Major Depression}

Major depression is a common and severe mental illness with a lifetime prevalence of $15 \%$ ( 1 in 6) compared with $1 \%$ for schizophrenia, and is twice as frequent in women as in men [1,2]. In developed countries, MDD currently accounts for the second highest lifetime burden of disease, and is forecast to be highest by 2030 [3-7]. With current antidepressant treatments, although up to $60 \%$ of patients respond, only $30 \%$ go on to remission [8-13], and $15 \%$ attempt suicide $[14,15]$. Although other neurotransmitters (e.g., noradrenaline, dopamine, glutamate, neurotrophins) are indirectly involved in depression [16-21], multiple lines of evidence implicate reduced 5-HT neurotransmission as a primary defect in depression [22-30]. For example, acute tryptophan depletion triggers relapse in recovered depressed patients, and elicits a depressed mood in normal subjects, while most antidepressant treatments, including serotonin-selective reuptake inhibitor (SSRIs), increase 5-HT neurotransmission either directly or indirectly

\footnotetext{
* Correspondence: palbert@uottawa.ca

Ottawa Hospital Research Institute (Neuroscience), University of Ottawa, 451 Smyth Road, Ottawa, Ontario, K1H 8M5, Canada
}

[20,31-34]. Alterations in 5-HT1A receptor levels are commonly observed in depressed individuals. In particular, post-synaptic 5-HT1A receptors are reduced in several cortical regions in depression [35-39] and anxiety [40-45], while 5-HT1A autoreceptors are increased in depression [46-48]. Elevated 5-HT1A autoreceptor expression would tend to reduce the activity of $5-\mathrm{HT}$ neurons, while reduced post-synaptic 5-HT1A receptors would result in a blunted behavioral response to 5- $\mathrm{HT}$. These studies implicate the $5-\mathrm{HT} 1 \mathrm{~A}$ receptor as an important determinant of predisposition to mental illness. However, the mechanisms underlying these differential changes in 5-HT1A receptor expression remain unclear. This review examines the evidence that alterations in transcriptional regulation of the 5-HT1A receptor could underlie its dys-regulation in mental illness.

\section{5-HT1A receptors and the 5-HT system 5-HT1A autoreceptor function}

The brain 5-HT system originates from neurons of the raphe nuclei that express tryptophan hydroxylase 2 (TPH2), the rate-limiting enzyme for 5-HT synthesis in the central nervous system [49-51] (Figure 1). These 


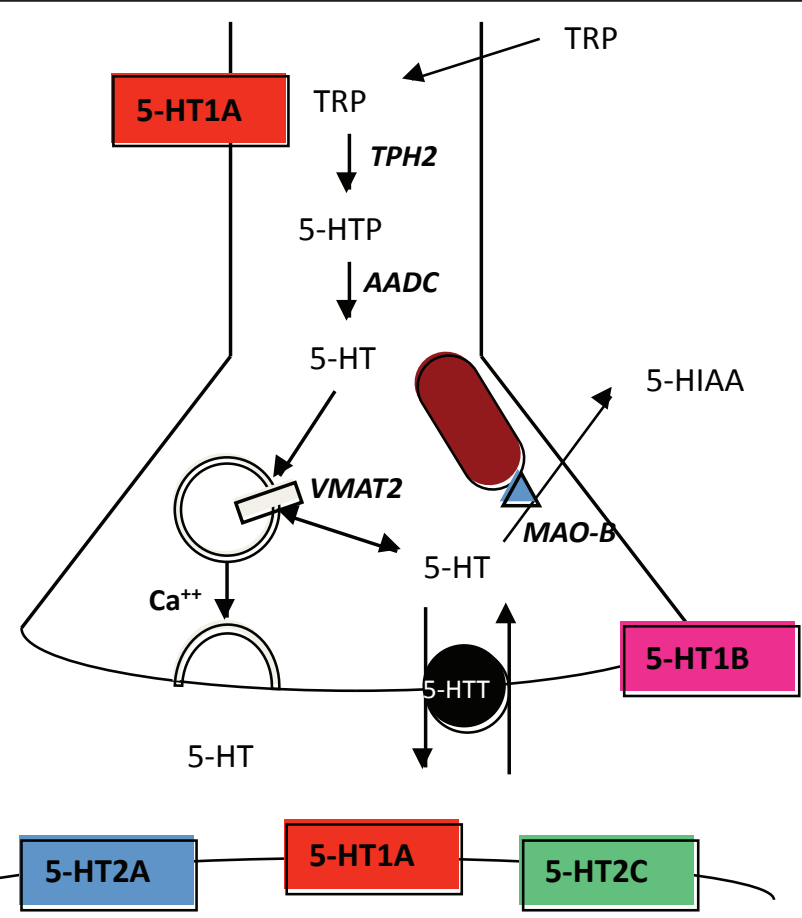

Figure 1 Components of $\mathbf{5 - H T}$ neurotransmission. Shown are the major components involved in the synthesis, vesicular packaging, reuptake, and degradation of serotonin in the brain, and the major receptors that mediate pre- and post-synaptic regulation of 5-HT neurotransmission. TRP, tryptophan; 5-HTP, 5-hydroxy-TRP; 5-HIAA, 5-hydroxy indole acetic acid; TPH2, tryptophan hydroxylase-2; AADC, aromatic amino-acid decarboxylase; VMAT2, vesicular monoamine transporter-2; MAO-B, monoamine oxidase B; 5-HTT, 5-HT transporter.

neurons project widely throughout the brain to regulate many functions, including sleep, mood, and stress reactivity [52-58] and are implicated in mental illnesses, including major depression and anxiety $[26,27,55,57,59]$. Among the 14 5-HT receptor genes [60], the 5-HT1A receptor is of particular interest since it is abundant in corticolimbic regions that are implicated in mood and emotion, such as the hippocampal and cortical pyramidal neurons and interneurons of the prefrontal cortex, medial septum, amygdala, hypothalamus, and other regions [60-64]. Presynaptically, the 5-HT1A receptor is the major somatodendritic autoreceptor on 5-HT neurons [65-67] where it acts as a "brake" to inhibit the activity of the entire 5-HT system and is thought to delay antidepressant response [68-74] (Figure 2). Hence mechanisms that regulate 5-HT1A autoreceptor levels are likely to set the tone of the entire 5-HT system and thus influence susceptibility to mood disorders such as depression, anxiety, and related disorders.

\section{Signaling of the 5-HT1A autoreceptor}

The 5-HT1A receptor was the first 5-HT receptor cloned and encodes a protein with seven hydrophobic transmembrane domains, typical of G-protein coupled receptors $[61,75]$ (Figure 3). The 5-HT1A receptor couples to $\mathrm{Gi} / \mathrm{Go}$ proteins, and in most cells and inhibits adenylyl cyclase activation, reducing cAMP levels [76,77]. Several studies have investigated the signaling of the 5-HT1A autoreceptor in raphe neurons [78]. This is also the case in the raphe nucleus, where the 5-HT1A autoreceptor preferentially couples to Gai3 $[79,80]$, and negatively regulates serotonergic neuronal activity, in part by inhibiting adenylyl cyclase [80-83]. Interestingly, signaling to this pathway depends on the 5-HT1A agonist used $[82,84,85]$. In addition, the 5-HT1A autoreceptor also activates GIRK potassium channels to inhibit neuronal firing [86-89], and inhibits voltage-gated calcium channel activity to reduce calcium entry [90-92] (Figure 3). In post-synaptic cortical neurons, 5-HT1Amediated inhibition of cAMP is thought to reduce CAMKII activity and to reduce AMPA receptor levels [93]. In hippocampal neurons, 5-HT1A receptor activation leads to activation of Akt and inactivation of GSK3 $\beta$ [94-96], which is also seen in raphe cultures [97], but has no effect on basal ERK1/2 phosphorylation $[95,97]$. Using rat raphe RN46A cells, a model of serotonergic neurons that express endogenous 5-HT1A autoreceptors $[98,99]$, we found that 5 -HT1A receptors signaled to inhibit of adenylyl cyclase and ERK1/2 phosphorylation, and that ERK1/2 inhibition was augmented upon differentiation of the cells to a serotonergic phenotype [100]. Similarly, in cortical neurons and human 


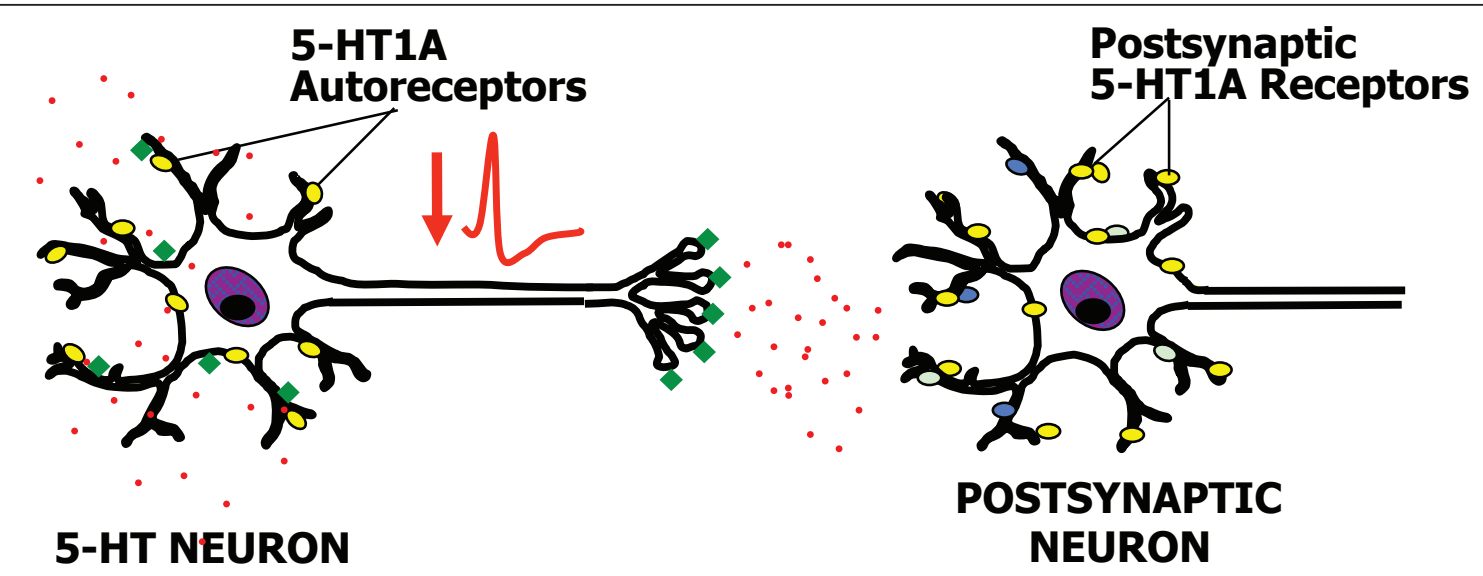

Figure 2 5-HT1A autoreceptor-mediated negative feedback on 5-HT neurons. A model of a serotonergic neuron (5-HT neuron) projecting to a target neuron (postsynaptic neuron) is shown, with 5-HT1A receptors depicted as yellow ovals, and other 5-HT receptors as other colored ovals. Acutely, SSRI's rapidly enter the brain and block 5-HT transporters (green diamonds), located at the raphe serotonin nerve terminal, but also at the cell body and dendrites in the raphe nuclei. This block of reuptake leads to accumulation of extracellular 5-HT (red dots) at both sites once released by depolarization. Activation of 5-HT1A autoreceptors located at the cell body and dendrites leads to inhibition of neuronal firing rate (red action potential), thus compensating for increase in 5-HT induced by SSRI treatment, resulting in little change in 5-HT

neurotransmission initially.

neuronal cultures, the 5-HT1A receptor also inhibits ERK1/2 activation [101,102]. Thus, modulation of ERK1/2 activity may be cell- and maturation-dependent and may also depend on the expression of negative regulators of this pathway (such as MKP or PP2A) $[103,104]$. Therefore, in the raphe, the signaling of the 5-HT1A autoreceptor appears to be largely inhibitory.

5-HT1A receptors and antidepressant response Although antidepressants such as SSRIs, rapidly block 5HT reuptake, chronic 3-wk treatment is required for clinical improvement and desensitization of the 5-HT1A autoreceptor has been implicated in this delay (Figure 3).
Blier, de Montigny and colleagues demonstrated that multiple antidepressant treatments reduce auto-inhibition of serotonergic activity in the raphe nuclei by 5 HT1A autoreceptors, and in some cases sensitize responses of post-synaptic 5-HT1A receptors [105]. This work has led to the concept that chronic desensitization of the 5-HT1A autoreceptor is necessary to achieve increased serotonergic neurotransmission following antidepressant treatment [106-109] and to increase serotonin synthesis [110]. Consistent with this, the level of 5-HT1A autoreceptors is negatively correlated with raphe $5-\mathrm{HT}$ synthesis in human subjects [74]. The prolonged time course of 5-HT1A desensitization is consistent with

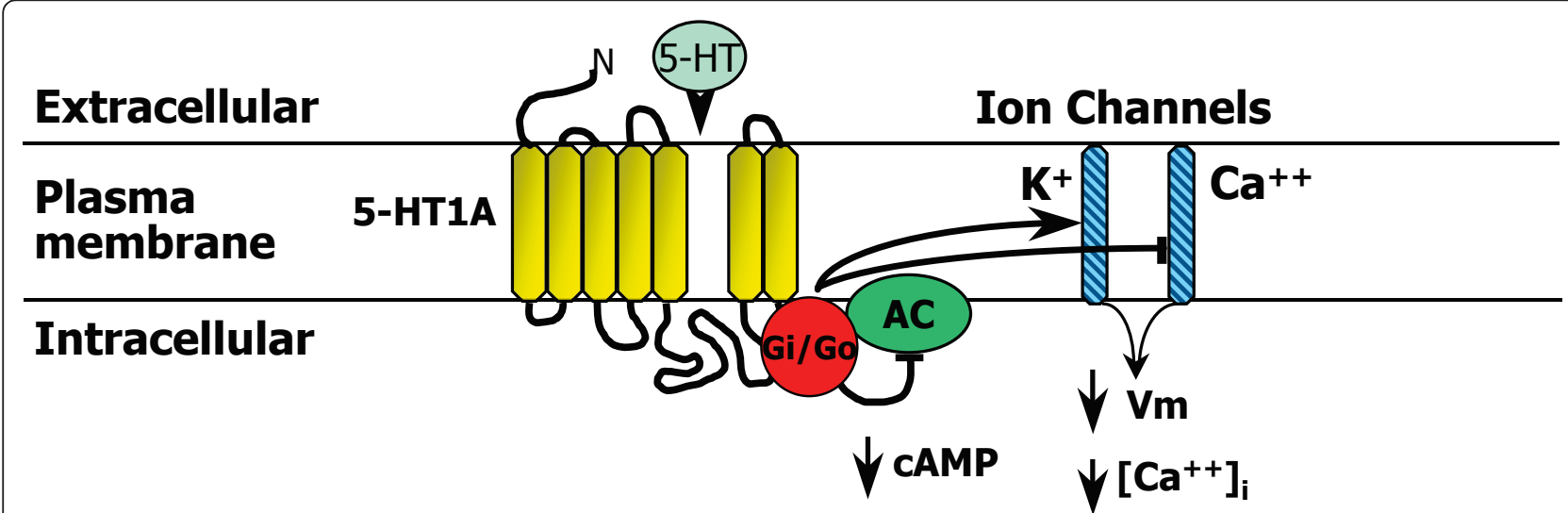

Figure 3 Neuronal signaling of the $\mathbf{5 - H T 1 A}$ autoreceptor. The major signaling pathways of the 5-HT1A receptor in neurons are shown. The 5-HT1A receptor is shown figuratively as a heptahelical G-protein coupled receptor that couples via inhibitory G proteins (Gi/Go) to inhibit adenylyl cyclase (AC) and reduce CAMP levels; to open G-protein inward rectifying potassium channels $\left(\mathrm{K}^{+}\right)$to reduce membrane potential $(\mathrm{Vm})$; and to inhibit voltage-gated calcium channels $\left(\mathrm{Ca}^{++}\right)$and reduce intracellular free calcium concentration $\left(\left[\mathrm{Ca}^{++}\right]_{\mathrm{i}}\right)$. 
adaptive reduction in 5-HT1A receptor expression, as opposed to more rapid forms of desensitization such as receptor uncoupling or internalization. In studies of normal animals chronically treated with SSRIs, only acute desensitization of the autoreceptor is observed, with no changes in 5-HT1A autoreceptor RNA or protein levels in the raphe [111-113]. In contrast, studies in chronically stressed or older animals [114] have shown reductions in 5-HT1A RNA in raphe nuclei following chronic antidepressant treatment. During chronic SSRI treatment, 5HT1A autoreceptors desensitize [107,115-119], leading to reduced 5-HT1A autoreceptor levels in animal depression models and depressed subjects [110,120-125], and restoration of raphe firing activity and 5 - HT release. Thus both acute and chronic desensitization processes appear to be required for long-term inactivation of 5HT1A autoreceptors in SSRI treatment of depressed animal models. However, the mechanisms involved in the preferential down-regulation of 5-HT1A autoreceptors, but not post-synaptic 5-HT1A receptors following chronic antidepressant treatment remain to be clarified.

Upon treatment with SSRIs, it is presumed that as well as inhibiting 5-HT reuptake at the nerve terminals in target brain regions, 5-HT levels are increased at the cell body and dendrites of raphe neurons leading to autoinhibition (Figure 2). However, the mechanism by which SSRI treatment enhances 5-HT release in the raphe is unclear. Although recurrent collaterals or intraraphe cross-innervation occurs in culture [126], it has been difficult to demonstrate 5 -HT terminals in the raphe nuclei [112]. The finding that VMAT2 is targeted to dendrites for somatodendritic vesicular dopamine release [127-129] provides a new mechanism by which 5-HT may be released somatodendritically. Recent evidence suggests that somatodendritic 5 -HT release can occur, at least in culture [130]. But can transcriptional down-regulation account for a 3-week delay in antidepressant response? In cultured cells, siRNA can reduce target RNA within days, however, the half-life of 5HT1A receptor protein in vivo is several days following doxycycline-induced suppression [131,132]. Furthermore, unlike in culture where signaling to down-regulation is immediate, 5-HT1A-mediated signaling to transcriptional down-regulation is gradual in vivo since 5 -HT release is auto-inhibited and only gradually increases as autoreceptors become more desensitized, a process that may take weeks.

\section{5-HT1A receptors in animal models of depression}

Due to the limitations of heterogeneity in clinical samples and in the validity of animal models, our understanding of depression remains incomplete [30,133-135]. Nevertheless, mouse models have provided valuable insights into the role of 5-HT1A receptors in depression and anxiety. Importantly, 5-HT1A-null mice display increased anxiety behaviours [136-138] and are unresponsive to selective 5-HT reuptake inhibitor (SSRI) [139]. Conversely, global over-expression of the 5-HT1A receptor or enhancement of its post-synaptic signalling decreases anxiety $[96,140]$. Rescue of post-synaptic 5HT1A receptor expression in early postnatal forebrain restores a normal anxiety phenotype, while its inhibition from postnatal day 13-34 induces anxiety in the adult, suggesting it has a role in development of the anxiety phenotype $[131,141]$. 5-HT1A-dependent inhibition of CAMKII $\alpha$ appears to mediate the anxiety phenotype, since 5-HT1A-null mice with reduced CAMKII activation did not develop anxiety [141]. Recently, mice with a $30 \%$ decrease in 5-HT1A autoreceptors displayed increase in 5HT neuron firing rate and augmented 5-HT release, and reduced depression-like behavior but no change in anxiety [132]. Hence, reduced activity of post-synaptic 5-HT1A receptors is implicated in anxiety, while an increased transcription of 5-HT1A autoreceptors associates with depression and resistance to chronic SSRI treatment [142].

\section{Transcriptional Regulation of the 5-HT1A Receptor Gene}

Because acute desensitization (uncoupling and internalization) occurs rapidly (sec-min) and is rapidly reversible $[143,144]$, we postulated that reduced transcription of 5HT1A autoreceptors could account for the three-week delay in clinical response following antidepressant treatment $[108,142,145]$. Supporting this hypothesis, transgenic mice with only $30 \%$ repression of 5 -HT1A autoreceptors display an enhanced and rapid response to SSRIs [132], suggesting that transcriptional repression of the 5-HT1A autoreceptor could be key to an effective antidepressant response. In characterizing the 5-HT1A promoter, we have uncovered a number of important regulators at the minimal promoter, upstream repressor and enhancer regions, as well as at a C(-1019)G polymorphism, that could affect 5-HT1A autoreceptor expression (Figure 4).

\section{5-HT1A minimal promoter}

To examine the transcriptional regulation of the 5HT1A receptor gene, the promoter region has been characterized using transcriptional reporter assays in cultured cell lines $[99,108,146]$. Most non-neuronal cell lines and tissues express low or undetectable levels of 5HT1A receptors [61], while some neuronal cell lines express endogenous 5-HT1A receptors. In particular, the rat raphe RN46A cells are serotonergic and express 5-HT1A receptors, and can serve as a model for 5HT1A autoreceptor regulation [99]. While several nonserotonergic neuroblastoma cells (human SKN-SH, rodent NG108-15 and SN-48 cells) also express 5-HT1A 


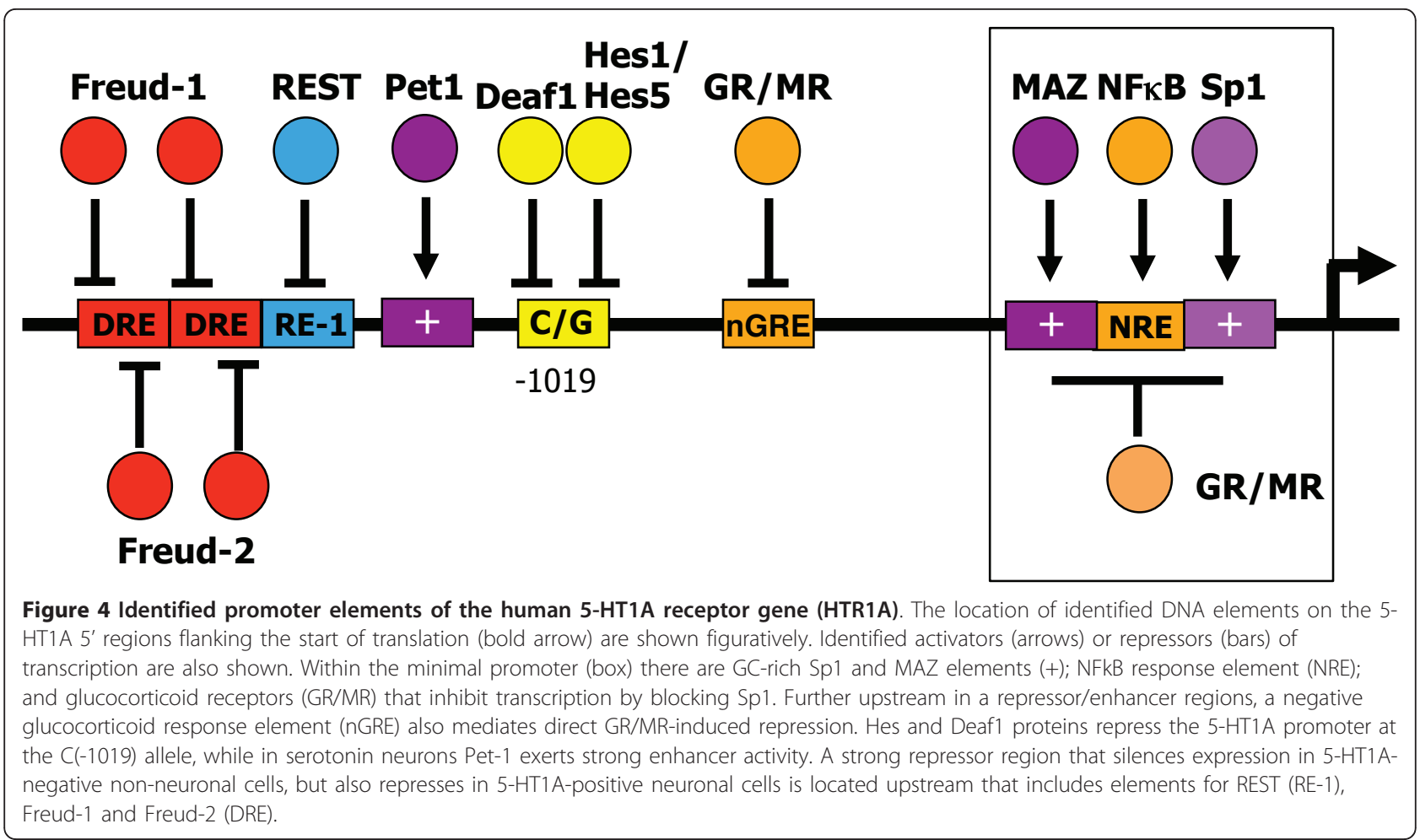

receptors and model post-synaptic 5-HT1A receptors [147-149]. The human and mouse 5-HT1A promoters lack a TATA box and have multiple transcription start sites, while the rat 5-HT1A promoter has a major TATA-driven start site $[99,146]$. Nevertheless, the minimal promoter located within $300 \mathrm{bp}$ upstream of the intronless coding sequence is highly conserved. This minimal promoter is typical of a "housekeeping" promoter and consists of a series of GC-rich enhancer elements recognized by the ubiquitous factors MAZ1 and Sp1 [146] that drive non-selective expression of the gene in all cell types, whether they express endogenous 5-HT1A receptors or not [99]. Within the minimal promoter, there is a conserved NFkB response element that may mediate induction of 5-HT1A expression by NFkB [150]. NFkB is observed in several types of immune cells including B- and T-lymphocytes, neutrophils and macrophages in which basal 5-HT1A receptor levels are very low, but can be greatly induced by mitogenic stimulation to augment the mitogenic response [151-153]. Finally, there is evidence that suppression of 5-HT1A receptor expression by glucocorticoids is mediated by inhibitory actions on the minimal promoter via $\mathrm{Sp} 1$ and NFkB elements [154].

\section{5-HT1A repressor region}

Located upstream from the minimal promoter is a series of repressor elements that silence 5-HT1A expression in non-neuronal cells, but also repress 5-HT1A transcription in neuronal cell lines that express 5-HT1A receptors $[155,156]$. Importantly these elements are conserved between human, rat and mouse genes and are functional. One of the key elements is a consensus repressor element-1 (RE-1) site that is recognized by REST/NRSF, a key pan-neuronal repressor of multiple neuronal genes [157-159]. REST has been shown to be crucial for silencing neuronal gene expression in neural stem cells or progenitors and non-neuronal cells, but is down-regulated upon neuronal differentiation, allowing for expression of neuronal genes. However, the 5-HT1A receptor is not expressed in all neuronal subtypes, hence additional repressors are required to restrict its expression to appropriate neurons. Located adjacent to the RE-1 site, we identified a dual repressor element (DRE, 31-bp) that mediates the strongest repression of the 5-HT1A promoter (Figure 4) [156]. In non-neuronal cells two nuclear protein complexes bind the DRE, one at the 5' end (FRE), and the other at the 3' end (TRE); however in raphe RN46A cells only the FRE-complex is present. In raphe RN46A cells, mutation of the FRE de-repressed 5-HT1A transcription by 10-fold, whereas in non-neuronal cells, deletion of the entire DRE was required. Using a yeast one-hybrid cloning approach Freud-1/CC2D1A (FRE Under Dual repression binding protein) was identified as a protein that binds and represses at the FRE site [160]; subsequently, the homologue Freud-2/ 
CC2D1B was identified as the second DRE-binding protein $[161,162]$. Freud-1 and Freud-2 are colocalized with 5 -HT1A receptors in neurons, where they play complementary roles to regulate the level of 5-HT1A receptor expression. In particular, Freud-1, but not Freud-2, is strongly expressed and colocalized with 5-HT and 5HT1A receptors in raphe nuclei, while both Freud-1 and Freud-2 are colocalized with the receptor in postsynaptic areas such as cortex and hippocampus $[161,163]$. Together, Freud-1 and Freud-2 mediate dual repression of 5-HT1A receptor expression in most cell types including many post-synaptic neurons to restrict 5-HT1A receptor expression to appropriate neurons. Based on its role in RN46A cells and its localization in 5-HT neurons in vivo, Freud-1 appears to be the dominant repressor of 5-HT1A autoreceptor expression. However, it is possible that in mental illness, other repressors may play a role. For example, REST expression is up-regulated in serotonergic raphe cells from depressed suicide as compared to control brains, and may restrain over-expression of 5-HT1A autoreceptors observed in these subjects [164].

Located between the minimal promoter and the upstream DRE is a region that exhibits both enhancer and repressor activities (Figure 4). Within this region, a novel type of negative glucocorticoid response element (nGRE), composed of two GRE half-sites separated by 6 nucleotides (rather than 3 nucleotides as for a typical consensus GRE) [165] was identified. The nGRE is conserved between human, mouse and rat, although its function has only been demonstrated for the rat nGRE thus far. The 5-HT1A nGRE mediates synergistic repression by both high and low affinity glucocorticoid receptors (MR and GR), suggesting a key role in repression of 5-HT1A receptors in the hippocampus, in which both these receptors are present [166]. In the raphe, only GR has been detected, and it appears to have a relatively weaker ability to suppress 5 -HT1A receptor expression compared to hippocampus [167-171]. Interestingly, 5-HT1A agonists downregulate GR in raphe cells in culture, which would lead to an increase in 5HT1A autoreceptors [172]. Conversely, knockdown of GR abrogates the down-regulation of 5-HT1A autoreceptors induced by chronic mild stress in mice [173]. Since glucocorticoids are dys-regulated in depression, the chronic elevation of cortisol may ultimately desensitize GR and could contribute to increase 5-HT1A autoreceptor expression in depression.

\section{C(-1019)G HTR1A polymorphism (rs6295)}

In our analysis of the 5-HT1A promoter we identified a human C(-1019)G 5-HT1A polymorphism located within the repressor/enhancer region. The $G$ allele and G/G genotype were associated with major depression and suicide $[174,175]$. Since the C(-1019)G polymorphism is located in a 26 -bp palindrome, we addressed whether this palindrome could bind protein in nuclear extracts of raphe RN46A cells, and showed a specific complex that preferentially recognized the C-allele over the G-allele. Using a yeast one-hybrid screen, Deaf1 (NUDR) and Hes5 were identified as repressors of the $\mathrm{C}$ - but not the G-allele of the 5-HT1A promoter (Figure 4). Deaf1 (Deformed autoregulatory factor-1) binds to a minimal TCG consensus sequence [176] present in the human, rat and mouse 5-HT1A genes [175] and can act as a repressor or enhancer [176,177]. By supershift analysis, Deaf1 was detected as a major component of the RN46A nuclear protein $\mathrm{C}$-allele palindrome-binding complex. When transfected in RN46A cells, Deaf1 suppressed 5-HT1A receptor transcription, and reduced 5HT1A RNA and protein expression. However, unlike Freud-1, while mutation of the palindrome blocked Deaf1 repression, it did not de-repress basal 5-HT1A transcription compared to mutation of the FRE, suggesting that Freud-1 is the predominant repressor of the autoreceptor in RN46A cells. In the adult rat and human brain, Deaf1 is colocalized with 5-HT1A receptors, and in the raphe nuclei it is also colocalized with 5-HT $[175,178]$. In other neuronal 5-HT1A-expressing cell types, instead of repressing 5-HT1A gene expression as seen in raphe or non-neuronal cells, Deaf1 enhances 5-HT1A expression, and the G-allele reduces basal 5HT1A expression [148]. Based on this dual activity of Deaf1, the G/G(-1019) genotype is expected to increase 5-HT1A autoreceptor levels to reduce 5-HT neuron firing, and decrease post-synaptic 5-HT1A receptors, thereby synergistically reducing 5 -HT neurotransmission (Figure 5). In support of this, depressed subjects homozygous for the 5-HT1A G/G(-1019) genotype have increased 5-HT1A autoreceptor binding potential [179-181], which is consistent with the increase in 5HT1A autoreceptors observed in post-mortem studies of depressed suicides [46-48]. Thus, the 5-HT1A G $(-1019)$ allele may alter 5 -HT1A receptor expression in vivo by blocking Deaf1 function.

The Hes proteins, which also preferentially recognize the HTR1A C(-1019) allele, appear to play an important role in regulating early induction of the 5-HT1A autoreceptor. Hes5, and especially Hes1, repress neuronal gene expression in neural precursor cells and are down-regulated upon neuronal differentiation [182]. We therefore addressed whether Hes1 can repress 5-HT1A receptor expression, and found that Hes1 exerts even stronger repression than either Hes5 or Deaf1. However, Deaf1 appears to be the dominant factor when the two are coexpressed [183]. To address whether Hes1 influences 5HT1A receptor expression in vivo, we examined embryonic midbrain tissue from the Hes1 -/- mice for 


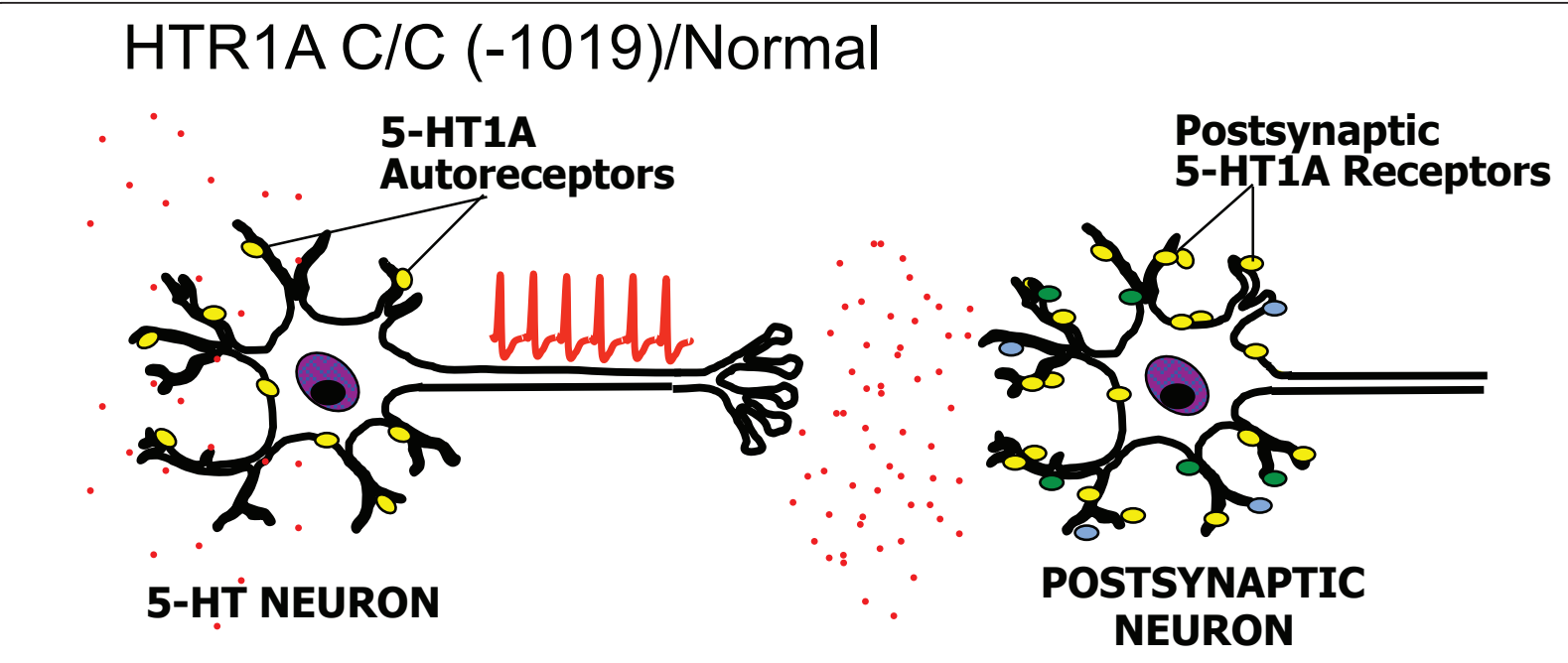

\section{HTR1A G/G (-1019)/Depressed}

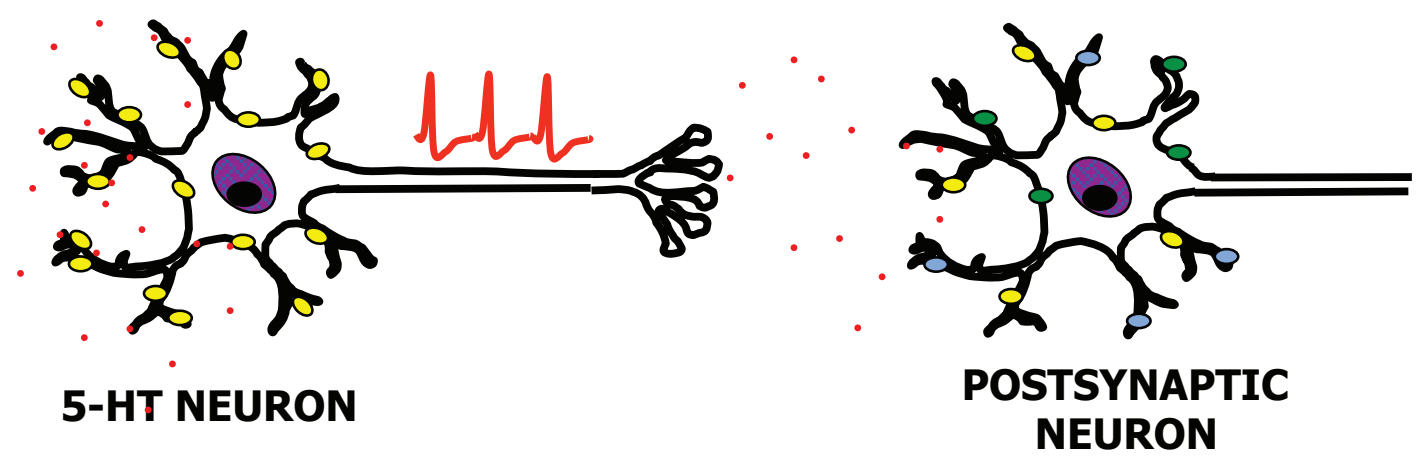

Figure 5 Proposed actions of 5-HT1A C(-1019)G genotype in normal vs. depressed subjects. In normal subjects containing homozygous HTR1A C/C (-1019) genotype, 5-HT neurons fire at their normal rate (red action potentials), releasing 5-HT (red dots) at the synapse for activation of receptors (ovals), and to a lesser degree at the raphe cell body to restrain neuronal activity by negative feedback through the 5-HT1A autoreceptor (yellow ovals). In the G/G genotype and in depressed subjects, 5-HT1A autoreceptor expression is increased which would reduce neuronal firing and 5-HT release, while post-synaptic 5-HT1A receptors are reduced in certain regions, which would decrease response to 5-HT release. Normal subjects with the G/G genotype have a lesser increase of 5-HT1A autoreceptors, and are able to compensate for the effect of the $\mathrm{G} / \mathrm{G}$ genotype on transcription.

5-HT1A receptor RNA levels at the initiation of serotonergic neuronal differentiation. We found that 5-HT1A RNA was prematurely upregulated with an expanded distribution of midbrain expression. Thus, reduction in repression by both Deaf1 and Hes proteins at the G-allele of the 5-HT1A promoter could lead to upregulation of 5HT1A autoreceptor expression beginning in early serotonergic differentiation and extending to adulthood.

The expression of Deaf1, Freud-1 and Freud-2 also appears to be dys-regulated in human depression in a region-specific manner $[161,164,178,184]$. In serotonergic raphe cells, both Deaf1 and REST are upregulated, and 5-HT1D receptor RNA is increased, and there is a trend for increased 5-HT1A and 5-HT1B RNA [164]. Hence, despite compensatory upregulation of repressors, there appears to be a general upregulation of 5-HT1 autoreceptor expression on serotonergic neurons. However, the G-allele would be expected to attenuate Deaf1 action on the 5-HT1A receptor gene.

\section{Pet-1 enhancer elements}

In addition to repression, 5-HT1A autoreceptor expression is subject to regulation by enhancers, the most important of which appears to be Pet-1. Pet-1 was 
identified as a critical regulator of 5-HT marker genes including TPH, 5-HTT, and ADC genes [185], and knockout of Pet-1 results in a substantial loss of serotonin in the brain, although a few 5-HT neurons appear to persist [186]. Hence we addressed whether Pet-1 regulates 5-HT1A receptor gene transcription [187]. There are several putative Pet-1 sites located in the 5-HT1A promoter, and deletion analysis demonstrated that while all of the sites have some activity, deletion of the upstream Pet-1 site located at -1406 bp reduced 5HT1A promoter activity by over $90 \%$, indicating a predominant role for this site. Consistent with a role for Pet-1 in regulation of 5-HT1A autoreceptor expression in vivo, the Pet-1 knockout mice demonstrated a nearly complete loss of 5-HT1A RNA and protein specifically in the raphe [187-189], while at post-synaptic target tissues 5-HT1A expression was modestly affected [187]. Thus, Pet-1 functions as a major enhancer of 5-HT1A autoreceptor expression. However, since Pet-1 is also required for TPH2 expression, blocking Pet-1 would actually reduce $5-\mathrm{HT}$ neurotransmission as shown in the Pet-1 knockout mice, which leads to an anxious and aggressive behavioral phenotype [186].

In summary, we have identified several key transcription factors, including REST, Freud-1, GR, Deaf1, Hes1 and Pet-1, which coordinately regulate 5 -HT1A autoreceptor expression and its modulation by glucocorticoids, 5-HT, and other neurotransmitters.

\section{5-HT1A Autoreceptors in Human Depression}

Given the role of 5-HT1A autoreceptors in regulation of the serotonin system and the importance of 5 - $\mathrm{HT}$ in clinical depression, several approaches have addressed whether 5-HT1A receptor expression is altered in depression. In depressed subjects, the observed increases in 5-HT1A autoreceptors could be due to increased 5HT1A autoreceptor transcription, while region-specific reductions in post-synaptic 5-HT1A receptors could result from reduced transcription in these regions. These changes in 5-HT1A receptors would result in a global reduction in 5-HT neurotransmission, and predisposition to depression (Figure 5). In agreement with this idea, the G(-1019) 5-HT1A allele, which leads to increased 5-HT1A autoreceptor transcription, has been associated with major depression and suicide [175], and this association has been replicated and extended in most [174,179,181,190-197], but not all studies [198]. The 5-HT1A G(-1019) allele has also been associated with anxiety [199-202]. Importantly, the 5-HT1A G/G genotype is associated with increased 5-HT1A autoreceptors in depressed subjects [179-181], suggesting that 5-HT1A G(-1019) allele is a risk factor for depression by increasing 5 -HT1A autoreceptor levels to reduce
5-HT neurotransmission $[108,145]$. Interestingly, studies in normal subjects have not found an association of the G/G genotype with depressed or anxious mood [203]. Furthermore, in normal subjects, although a trend for increased 5-HT1A autoreceptor levels with the G/G genotype is observed, it was not statistically significant [204]. These results suggest that although the G-allele may promote higher expression of 5-HT1A autoreceptors (Figure 5), normal subjects are able to compensate for the effect of the $\mathrm{G}$ allele, while depressed patients are not. For example, the absolute level of 5-HT1A receptors may differ between depressed and normal subjects due to differences in the regulation of 5 -HT1A expression (e.g., by increased glucocorticoids) or in the expression of 5-HTT, TPH2, MAO or other genes that influence the amount of 5-HT that is present extracellularly in the raphe $[205,206]$ and would indirectly affect the level of 5-HT1A autoreceptors through regulating autoreceptor desensitization. In addition, it is possible that impairment of Deaf1 action could account for increased levels of 5-HT1A autoreceptors in G/G subjects, and could also mediate a reduction in post-synaptic 5-HT1A receptors, suggesting Deaf1 as a potentially important mediator of transcriptional dys-regulation of the 5-HT1A receptor gene in depression.

An increase in 5-HT1A autoreceptor levels delays or prevents antidepressant response [132] and 3 weeks of treatment with antidepressants is required for clinical improvement, due to recurrent inhibition of raphe activity by the 5 -HT1A autoreceptor (Figure 2). One strategy to overcome negative feedback by 5-HT1A autoreceptor has been to use 5-HT1A partial agonists such as pindolol or buspirone, to block or desensitize the autoreceptor and accelerate SSRI action [207-209]. However, these compounds have insufficient specificity since they affect both pre-and post-synaptic receptors, and display only partial specificity for 5-HT1A autoreceptors $[210,211]$. We and others have found that the G(-1019) allele associates with reduced antidepressant response $[174,212-214]$, suggesting that regulation by Deaf1 could facilitate antidepressant response. Successful treatment of panic disorder patients with chronic SSRIs correlates with a normalization of pre- and post-synaptic 5-HT1A receptors, suggesting that down-regulation of pre-synaptic receptors concomitant with an up-regulation of postsynaptic 5-HT1A receptors may be critical for treatment response [45,215]. Among the transcriptional regulators of the 5-HT1A promoter, Deaf1 is of particular interest since it displays repressor activity on 5-HT1A autoreceptor expression, but enhancer activity on post-synaptic 5-HT1A receptors, a combination of activities that would normalize pre- and post-synaptic 5-HT1A receptor levels to enhance serotonergic neurotransmission. 


\section{Conclusion}

In conclusion, since dys-regulation of the 5-HT1A autoreceptor has the potential to affect the activity of the entire 5-HT system, it is critical to identify the transcriptional mechanisms underlying its long-term regulation. Understanding the transcription factors involved may provide important clues to the molecular mechanisms responsible for 5-HT1A receptor dys-regulation in mental illness. Transcriptional regulators of the 5-HT1A autoreceptor may also constitute important targets to restore normal levels of the receptor and improve treatment outcome for depression and related mental illnesses.

\section{Acknowledgements}

We wish to acknowledge grant support from the Canadian Institutes of Health Research (CIHR), Canadian Psychiatric Research Foundation, Heart and Stroke Foundation Centre for Stroke Recovery, and the Ontario Mental Health Foundation; A.M. was supported by a scholarship from CIHR. One of a series of four reviews on $\mathrm{G}$ protein-coupled receptors published in memory of Hubert H. M. Van Tol (1959-2006), formerly Head of Molecular Biology at the Centre for Addiction and Mental Health, and a Professor in the Departments of Psychiatry and Pharmacology at the University of Toronto. Hubert's contributions to $\mathrm{G}$ protein-coupled receptor research and neuroscience are numerous and are best remembered by his central role in the cloning of the dopamine receptor family. His many achievements were recognized through awards such as the John Dewan award, The Prix Galien, and the Joey \& Toby Tanenbaum Distinguished Scientist Award for Schizophrenia Research.

\section{Authors' contributions}

PA conceived of the topic, searched the literature and drafted the manuscript. BF and AM provided specific sections and corrections. All authors read and approved the final manuscript.

\section{Competing interests}

The authors declare that they have no competing interests.

Received: 1 April 2011 Accepted: 27 May 2011 Published: 27 May 2011

\section{References}

1. Doris A, Ebmeier K, Shajahan P: Depressive illness. Lancet 1999 354:1369-1375.

2. Fava M, Kendler KS: Major depressive disorder. Neuron 2000, 28:335-341.

3. Lopez AD, Murray CC: The global burden of disease, 1990-2020. Nat Med 1998, 4:1241-1243.

4. WHO: The World Health Report 2001. Mental Health, New Understanding, New Hope Geneva, Switzerland: WHO Marketing and Dissemination; 2001.

5. Mathers CD, Loncar D: Projections of global mortality and burden of disease from 2002 to 2030. PLoS Med 2006, 3:e442.

6. Ustun TB, Ayuso-Mateos JL, Chatterji S, Mathers C, Murray CJ: Global burden of depressive disorders in the year 2000. Br J Psychiatry 2004, 184:386-392

7. Murray CJ, Lopez AD: Global mortality, disability, and the contribution of risk factors: Global Burden of Disease Study. Lancet 1997, 349:1436-1442.

8. Rush AJ, Trivedi MH, Wisniewski SR, Stewart JW, Nierenberg AA, Thase ME, Ritz L, Biggs MM, Warden D, Luther JF, et al: Bupropion-SR, sertraline, or venlafaxine-XR after failure of SSRIs for depression. N Engl J Med 2006, 354:1231-1242

9. Trivedi MH, Rush AJ, Wisniewski SR, Nierenberg AA, Warden D, Ritz L, Norquist G, Howland RH, Lebowitz B, McGrath PJ, et al: Evaluation of outcomes with citalopram for depression using measurement-based care in $\operatorname{STAR}^{*} \mathrm{D}$ : implications for clinical practice. Am J Psychiatry 2006, 163:28-40.
10. Trivedi MH, Fava M, Wisniewski SR, Thase ME, Quitkin F, Warden D, Ritz L, Nierenberg AA, Lebowitz BD, Biggs MM, et al: Medication augmentation after the failure of SSRIs for depression. N Engl J Med 2006, 354:1243-1252.

11. Trivedi MH, Hollander E, Nutt D, Blier P: Clinical evidence and potential neurobiological underpinnings of unresolved symptoms of depression. J Clin Psychiatry 2008, 69:246-258.

12. Blier $P$, Ward HE, Tremblay $P$, Laberge $L$, Hebert $C$, Bergeron $R$ : Combination of Antidepressant Medications From Treatment Initiation for Major Depressive Disorder: A Double-Blind Randomized Study. Am J Psychiatry 2010, 167:281-288.

13. Deshauer D, Moher D, Fergusson D, Moher E, Sampson M, Grimshaw J: Selective serotonin reuptake inhibitors for unipolar depression: a systematic review of classic long-term randomized controlled trials. Cmaj 2008, 178:1293-1301.

14. Anguelova M, Benkelfat C, Turecki G: A systematic review of association studies investigating genes coding for serotonin receptors and the serotonin transporter: I. Affective disorders. Mol Psychiatry 2003, 8:574-591.

15. Arango V, Huang $Y$, Underwood MD, Mann JJ: Genetics of the serotonergic system in suicidal behavior. J Psychiatr Res 2003, 37:375-386.

16. Duman RS: Role of neurotrophic factors in the etiology and treatment of mood disorders. Neuromolecular Med 2004, 5:11-26.

17. Nestler EJ, Carlezon WA Jr: The mesolimbic dopamine reward circuit in depression. Biol Psychiatry 2006, 59:1151-1159.

18. Warner-Schmidt JL, Duman RS: Hippocampal neurogenesis: opposing effects of stress and antidepressant treatment. Hippocampus 2006, 16:239-249.

19. Covington HE, Vialou V, Nestler EJ: From synapse to nucleus: Novel targets for treating depression. Neuropharmacology 2010, 58:683-693.

20. Blier P: The pharmacology of putative early-onset antidepressant strategies. Eur Neuropsychopharmacol 2003, 13:57-66.

21. Skolnick P, Popik P, Trullas R: Glutamate-based antidepressants: 20 years on. Trends Pharmacol Sci 2009, 30:563-569.

22. aan het Rot M, Mathew SJ, Charney DS: Neurobiological mechanisms in major depressive disorder. CMAJ 2009, 180:305-313.

23. Millan MJ: The role of monoamines in the actions of established and "novel" antidepressant agents: a critical review. Eur J Pharmacol 2004, 500:371-384.

24. Wong DT, Perry KW, Bymaster FP: Case history: the discovery of fluoxetine hydrochloride (Prozac). Nat Rev Drug Discov 2005, 4:764-774.

25. Tremblay $P$, Blier P: Catecholaminergic strategies for the treatment of major depression. Curr Drug Targets 2006, 7:149-158.

26. Charney DS, Krystal JH, Delgado PL, Heninger GR: Serotonin-specific drugs for anxiety and depressive disorders. Annu Rev Med 1990, 41:437-446.

27. Mann JJ: Role of the serotonergic system in the pathogenesis of major depression and suicidal behavior. Neuropsychopharmacology 1999, 21:99S-105S

28. Jans LA, Riedel WJ, Markus CR, Blokland A: Serotonergic vulnerability and depression: assumptions, experimental evidence and implications. $\mathrm{Mol}$ Psychiatry 2007, 12:522-543.

29. Bhagwagar Z, Cowen PJ: 'It's not over when it's over': persistent neurobiological abnormalities in recovered depressed patients. Psychol Med 2008, 38:307-313.

30. Mann JJ, Arango VA, Avenevoli S, Brent DA, Champagne FA, Clayton P, Currier D, Dougherty DM, Haghighi F, Hodge SE, et al: Candidate endophenotypes for genetic studies of suicidal behavior. Biol Psychiatry 2009, 65:556-563.

31. Pineyro G, Blier P: Autoregulation of serotonin neurons: role in antidepressant drug action. Pharmacol Rev 1999, 51:533-591.

32. Blier $\mathrm{P}$, Ward NM: Is there a role for $5-\mathrm{HT}(1 \mathrm{~A})$ agonists in the treatment of depression? Biol Psychiatry 2003, 53:193-203.

33. Berton $\mathrm{O}$, Nestler EJ: New approaches to antidepressant drug discovery: beyond monoamines. Nat Rev Neurosci 2006, 7:137-151.

34. Hamani C, Diwan M, Macedo CE, Brandao ML, Shumake J, Gonzalez-Lima F, Raymond R, Lozano AM, Fletcher PJ, Nobrega JN: Antidepressant-like effects of medial prefrontal cortex deep brain stimulation in rats. Biol Psychiatry 2010, 67:117-124.

35. Shively CA, Friedman DP, Gage HD, Bounds MC, Brown-Proctor C, Blair JB, Henderson JA, Smith MA, Buchheimer N: Behavioral depression and positron emission tomography-determined serotonin $1 \mathrm{~A}$ receptor 
binding potential in cynomolgus monkeys. Arch Gen Psychiatry 2006, 63:396-403.

36. Sargent PA, Kjaer KH, Bench CJ, Rabiner EA, Messa C, Meyer J, Gunn RN, Grasby PM, Cowen PJ: Brain serotonin $1 \mathrm{~A}$ receptor binding measured by positron emission tomography with [11C]WAY-100635: effects of depression and antidepressant treatment. Arch Gen Psychiatry 2000, 57:174-180.

37. Bhagwagar Z, Rabiner EA, Sargent PA, Grasby PM, Cowen PJ: Persistent reduction in brain serotonin $1 \mathrm{~A}$ receptor binding in recovered depressed men measured by positron emission tomography with [11C]WAY100635. Mol Psychiatry 2004, 9:386-392.

38. Moses-Kolko EL, Wisner KL, Price JC, Berga SL, Drevets WC, Hanusa BH, Loucks TL, Meltzer CC: Serotonin 1A receptor reductions in postpartum depression: a positron emission tomography study. Fertil Steril 2008, 89:685-692.

39. Stockmeier CA, Howley E, Shi X, Sobanska A, Clarke G, Friedman L, Rajkowska G: Antagonist but not agonist labeling of serotonin-1A receptors is decreased in major depressive disorder. J Psychiatr Res 2009, 43:887-894.

40. Neumeister A, Bain E, Nugent AC, Carson RE, Bonne O, Luckenbaugh DA, Eckelman W, Herscovitch P, Charney DS, Drevets WC: Reduced serotonin type 1 A receptor binding in panic disorder. J Neurosci 2004, 24:589-591.

41. Sullivan GM, Oquendo MA, Simpson N, Van Heertum RL, Mann JJ, Parsey RV: Brain serotonin1A receptor binding in major depression is related to psychic and somatic anxiety. Biol Psychiatry 2005, 58:947-954.

42. Lanzenberger RR, Mitterhauser M, Spindelegger C, Wadsak W, Klein N, Mien LK, Holik A, Attarbaschi T, Mossaheb N, Sacher J, et al: Reduced serotonin-1A receptor binding in social anxiety disorder. Biol Psychiatry 2007, 61:1081-1089.

43. Tauscher J, Bagby RM, Javanmard M, Christensen BK, Kasper S, Kapur S: Inverse relationship between serotonin $5-\mathrm{HT}(1 \mathrm{~A})$ receptor binding and anxiety: a [(11)C]WAY-100635 PET investigation in healthy volunteers. Am J Psychiatry 2001, 158:1326-1328.

44. Akimova $E$, Lanzenberger $R$, Kasper $S$ : The serotonin-1A receptor in anxiety disorders. Biol Psychiatry 2009, 66:627-635.

45. Nash JR, Sargent PA, Rabiner EA, Hood SD, Argyropoulos SV, Potokar JP, Grasby PM, Nutt DJ: Serotonin 5-HT1A receptor binding in people with panic disorder: positron emission tomography study. Br J Psychiatry 2008, 193:229-234.

46. Drevets WC, Thase ME, Moses-Kolko EL, Price J, Frank E, Kupfer DJ, Mathis C: Serotonin-1A receptor imaging in recurrent depression: replication and literature review. Nucl Med Biol 2007, 34:865-877.

47. Boldrini M, Underwood MD, Mann JJ, Arango V: Serotonin-1A autoreceptor binding in the dorsal raphe nucleus of depressed suicides. J Psychiatr Res 2008, 42:433-442.

48. Stockmeier CA, Shapiro LA, Dilley GE, Kolli TN, Friedman L, Rajkowska G: Increase in serotonin-1A autoreceptors in the midbrain of suicide victims with major depression-postmortem evidence for decreased serotonin activity. I Neurosci 1998, 18:7394-7401.

49. Walther DJ, Peter JU, Bashammakh S, Hortnagl H, Voits M, Fink H, Bader M: Synthesis of serotonin by a second tryptophan hydroxylase isoform. Science 2003, 299:76.

50. Zhang X, Gainetdinov RR, Beaulieu JM, Sotnikova TD, Burch LH, Williams RB, Schwartz DA, Krishnan KR, Caron MG: Loss-of-function mutation in tryptophan hydroxylase-2 identified in unipolar major depression. Neuron 2005, 45:11-16.

51. Savelieva KV, Zhao S, Pogorelov VM, Rajan I, Yang Q, Cullinan E, Lanthorn TH: Genetic disruption of both tryptophan hydroxylase genes dramatically reduces serotonin and affects behavior in models sensitive to antidepressants. PLOS ONE 2008, 3:e3301.

52. Törk I: Anatomy of the serotonergic system. Ann N Y Acad Sci 1990, 600:9-34, discussion 34-35.

53. Fuller RW: Serotonin receptors and neuroendocrine responses. Neuropsychopharmacology 1990, 3:495-502.

54. Jacobs BL, Azmitia EC: Structure and function of the brain serotonin system. Physiol Rev 1992, 72:165-229.

55. Barnes NM, Sharp T: A review of central 5-HT receptors and their function. Neuropharmacology 1999, 38:1083-1152.

56. Hornung JP: The human raphe nuclei and the serotonergic system. $J$ Chem Neuroanat 2003, 26:331-343.
57. Gordon JA, Hen R: The serotonergic system and anxiety. Neuromolecular Med 2004, 5:27-40.

58. Lanfumey L, Mongeau R, Cohen-Salmon C, Hamon M: Corticosteroidserotonin interactions in the neurobiological mechanisms of stressrelated disorders. Neurosci Biobehav Rev 2008, 32:1174-1184.

59. Young SN, Leyton M: The role of serotonin in human mood and social interaction. Insight from altered tryptophan levels. Pharmacol Biochem Behav 2002, 71:857-865.

60. Hoyer D, Clarke DE, Fozard JR, Hartig PR, Martin GR, Mylecharane EJ, Saxena PR, Humphrey PP: International Union of Pharmacology classification of receptors for 5-hydroxytryptamine (Serotonin). [Review]. Pharmacol Rev 1994, 46:157-203.

61. Albert PR, Zhou QY, Van Tol HH, Bunzow JR, Civelli O: Cloning, functional expression, and mRNA tissue distribution of the rat 5hydroxytryptamine1A receptor gene. J Biol Chem 1990, 265:5825-5832.

62. Chalmers DT, Watson SJ: Comparative anatomical distribution of 5-HT1A receptor mRNA and 5-HT1A binding in rat brain-a combined in situ hybridisation/in vitro receptor autoradiographic study. Brain Res 1991, 561:51-60.

63. Pompeiano M, Palacios JM, Mengod G: Distribution and cellular localization of mRNA coding for 5-HT1A receptor in the rat brain: correlation with receptor binding. J Neurosci 1992, 12:440-453.

64. Palchaudhuri M, Flugge G: 5-HT1A receptor expression in pyramidal neurons of cortical and limbic brain regions. Cell Tissue Res 2005, 321:159-172.

65. Verge D, Daval G, Patey A, Gozlan H, el Mestikawy S, Hamon M: Presynaptic 5-HT autoreceptors on serotonergic cell bodies and/or dendrites but not terminals are of the 5-HT1A subtype. Eur J Pharmacol 1985, 113:463-464

66. Sotelo C, Cholley B, EM S, Gozlan H, Hamon M: Direct immunohistochemical evidence of the existence of 5-HT1A autoreceptors on serotoninergic neurons in the midbrain raphe nuclei. Eur J Neurosci 1990, 2:1144-1154.

67. Riad M, Garcia S, Watkins KC, Jodoin N, Doucet E, Langlois X, el Mestikawy S, Hamon M, Descarries L: Somatodendritic localization of 5HT1A and preterminal axonal localization of $5-\mathrm{HT} 1 \mathrm{~B}$ serotonin receptors in adult rat brain. $J$ Comp Neurol 2000, 417:181-194.

68. Richer M, Hen R, Blier P: Modification of serotonin neuron properties in mice lacking 5-HT1A receptors. Eur J Pharmacol 2002, 435:195-203.

69. Hjorth S, Auerbach SB: Further evidence for the importance of 5-HT1A autoreceptors in the action of selective serotonin reuptake inhibitors. Eur J Pharmacol 1994, 260:251-255.

70. Hjorth S, Bengtsson HJ, Milano S: Raphe 5-HT1A autoreceptors, but not postsynaptic 5-HT1A receptors or beta-adrenoceptors, restrain the citalopram-induced increase in extracellular 5-hydroxytryptamine in vivo. Eur J Pharmacol 1996, 316:43-47.

71. Romero L, Artigas F: Preferential potentiation of the effects of serotonin uptake inhibitors by 5 -HT1A receptor antagonists in the dorsal raphe pathway: role of somatodendritic autoreceptors. J Neurochem 1997, 68:2593-2603

72. Liu RJ, Lambe EK, Aghajanian GK: Somatodendritic autoreceptor regulation of serotonergic neurons: dependence on L-tryptophan and tryptophan hydroxylase-activating kinases. Eur J Neurosci 2005, 21:945-958.

73. Bortolozzi A, Amargos-Bosch M, Toth M, Artigas F, Adell A: In vivo efflux of serotonin in the dorsal raphe nucleus of 5-HT1A receptor knockout mice. J Neurochem 2004, 88:1373-1379.

74. Frey BN, Rosa-Neto P, Lubarsky S, Diksic M: Correlation between serotonin synthesis and 5-HT1A receptor binding in the living human brain: a combined alpha-[11C]MT and [18F]MPPF positron emission tomography study. Neuroimage 2008, 42:850-857.

75. Fargin A, Raymond JR, Lohse MJ, Kobilka BK, Caron MG, Lefkowitz RJ: The genomic clone $\mathrm{G}-21$ which resembles a beta-adrenergic receptor sequence encodes the 5-HT1A receptor. Nature 1988, 335:358-360.

76. Raymond JR, Mukhin YV, Gettys TW, Garnovskaya MN: The recombinant 5HT1A receptor: G protein coupling and signalling pathways. Br J Pharmacol 1999, 127:1751-1764.

77. Albert PR, Robillard L: G protein specificity: traffic direction required. Cell Signal 2002, 14:407-418.

78. Polter AM, Li X: 5-HT1A receptor-regulated signal transduction pathways in brain. Cell Signal 2010, 22:1406-1412. 
79. Mannoury la Cour C, El Mestikawy S, Hanoun N, Hamon M, Lanfumey L: Regional differences in the coupling of 5-hydroxytryptamine-1A receptors to $\mathrm{G}$ proteins in the rat brain. Mol Pharmacol 2006, 70:1013-1021.

80. Valdizan EM, Castro E, Pazos A: Agonist-dependent modulation of Gprotein coupling and transduction of $5-\mathrm{HT} 1 \mathrm{~A}$ receptors in rat dorsal raphe nucleus. Int J Neuropsychopharmacol 2010, 13:835-843.

81. Liu YF, Ghahremani MH, Rasenick MM, Jakobs KH, Albert PR: Stimulation of CAMP Synthesis by Gi-coupled receptors upon ablation of distinct Galphai protein expression. Gi subtype specificity of the 5-HT1A receptor. J Biol Chem 1999, 274:16444-16450.

82. Marazziti D, Palego L, Giromella A, Mazzoni MR, Borsini F, Mayer N, Naccarato AG, Lucacchini A, Cassano GB: Region-dependent effects of flibanserin and buspirone on adenylyl cyclase activity in the human brain. Int J Neuropsychopharmacol 2002, 5:131-140.

83. Palego L, Giromella A, Marazziti D, Borsini F, Naccarato AG, Giannaccini G, Lucacchini A, Cassano GB, Mazzoni MR: Effects of postmortem delay on serotonin and $(+) 8-\mathrm{OH}-\mathrm{DPAT}$-mediated inhibition of adenylyl cyclase activity in rat and human brain tissues. Brain Res 1999, 816:165-174

84. Clarke WP, Yocca FD, Maayani S: Lack of 5-hydroxytryptamine1Amediated inhibition of adenylyl cyclase in dorsal raphe of male and female rats. Journal of Pharmacology \& Experimental Therapeutics 1996, 277:1259-1266.

85. Johnson RG, Fiorella D, Winter JC, Rabin RA: [3H]8-OH-DPAT labels a 5-HT site coupled to inhibition of phosphoinositide hydrolysis in the dorsal raphe. Eur J Pharmacol 1997, 329:99-106.

86. Penington NJ, Kelly JS, Fox AP: Whole-cell recordings of inwardly rectifying $\mathrm{K}+$ currents activated by $5-\mathrm{HT} 1 \mathrm{~A}$ receptors on dorsal raphe neurones of the adult rat. J Physiol 1993, 469:387-405.

87. Bayliss DA, Li YW, Talley EM: Effects of serotonin on caudal raphe neurons: activation of an inwardly rectifying potassium conductance. $J$ Neurophysio/ 1997, 77:1349-1361.

88. Ehrengruber MU, Doupnik CA, Xu Y, Garvey J, Jasek MC, Lester HA, Davidson $\mathrm{N}$ : Activation of heteromeric $\mathrm{G}$ protein-gated inward rectifier $\mathrm{K}$ + channels overexpressed by adenovirus gene transfer inhibits the excitability of hippocampal neurons. Proc Natl Acad Sci USA 1997, 94:7070-7075

89. Loucif AJ, Bonnavion P, Macri B, Golmard JL, Boni C, Melfort M, Leonard G, Lesch KP, Adrien J, Jacquin TD: Gender-dependent regulation of Gprotein-gated inwardly rectifying potassium current in dorsal raphe neurons in knock-out mice devoid of the 5-hydroxytryptamine transporter. J Neurobiol 2006, 66:1475-1488.

90. Chen $Y$, Penington NJ: Differential effects of protein kinase $C$ activation on 5 -HT1A receptor coupling to $\mathrm{Ca} 2+$ and $\mathrm{K}+$ currents in rat serotonergic neurones. J Physiol 1996, 496:129-137.

91. Penington NJ, Fox AP: Toxin-insensitive Ca current in dorsal raphe neurons. J Neurosci 1995, 15:5719-5726.

92. Bayliss DA, Li YW, Talley EM: Effects of serotonin on caudal raphe neurons: inhibition of $\mathrm{N}$ - and P/Q- type calcium channels and the afterhyperpolarization. J Neurophysiol 1997, 77:1362-1374.

93. Cai X, Gu Z, Zhong P, Ren Y, Yan Z: Serotonin 5-HT1A receptors regulate AMPA receptor channels through inhibiting $\mathrm{Ca} 2+$ /calmodulin-dependent kinase II in prefrontal cortical pyramidal neurons. J Biol Chem 2002, 277:36553-36562.

94. Chen S, Owens GC, Crossin KL, Edelman DB: Serotonin stimulates mitochondrial transport in hippocampal neurons. Mol Cell Neurosci 2007, 36:472-483.

95. Cowen DS, Johnson-Farley NN, Travkina T: 5-HT receptors couple to activation of Akt, but not extracellular-regulated kinase (ERK), in cultured hippocampal neurons. J Neurochem 2005, 93:910-917.

96. Talbot JN, Jutkiewicz EM, Graves SM, Clemans CF, Nicol MR, Mortensen RM, Huang X, Neubig RR, Traynor JR: RGS inhibition at G(alpha)i2 selectively potentiates 5-HT1A-mediated antidepressant effects. Proc Natl Acad Sci USA 2010, 107:11086-11091.

97. Druse M, Tajuddin NF, Gillespie RA, Le P: Signaling pathways involved with serotonin $1 \mathrm{~A}$ agonist-mediated neuroprotection against ethanolinduced apoptosis of fetal rhombencephalic neurons. Brain Res Dev Brain Res 2005, 159:18-28

98. Eaton MJ, Whittemore SR: Adrenocorticotropic hormone activation of adenylate cyclase in raphe neurons: multiple regulatory pathways control serotonergic neuronal differentiation. J Neurobiol 1995, 28:465-481.

99. Storring JM, Charest $A$, Cheng P, Albert PR: TATA-driven transcriptional initiation and regulation of the rat serotonin $5-\mathrm{HT} 1 \mathrm{~A}$ receptor gene. $J$ Neurochem 1999, 72:2238-2247.

100. Kushwaha N, Albert PR: Coupling of 5-HT1A autoreceptors to inhibition of mitogen-activated protein kinase activation via Gbetagamma subunit signaling. Eur J Neurosci 2005, 21:721-732.

101. Zhong P, Yuen EY, Yan Z: Modulation of neuronal excitability by serotonin-NMDA interactions in prefrontal cortex. Mol Cell Neurosci 2008 38:290-299.

102. Sjogren B, Csoregh L, Svenningsson P: Cholesterol reduction attenuates 5HT1A receptor-mediated signaling in human primary neuronal cultures. Naunyn Schmiedebergs Arch Pharmacol 2008, 378:441-446.

103. Chang CW, Poteet E, Schetz JA, Gumus ZH, Weinstein H: Towards a quantitative representation of the cell signaling mechanisms of hallucinogens: measurement and mathematical modeling of 5-HT1A and 5-HT2A receptor-mediated ERK1/2 activation. Neuropharmacology 2009, 56(Suppl 1):213-225.

104. Albert PR, Tiberi M: Receptor signaling and structure: insights from serotonin-1 receptors. Trends Endocrinol Metab 2001, 12:453-460.

105. Blier $P$, de Montigny $C$, Chaput $Y$ : Modifications of the serotonin system by antidepressant treatments: implications for the therapeutic response in major depression. J Clin Psychopharmacol 1987, 7:24S-35S.

106. Hjorth S: Serotonin $5-\mathrm{HT}_{1 \mathrm{~A}}$ autoreceptor blockade potentiates the ability of the 5-HT reuptake inhibitor citalopram to increase nerve terminal output of 5-HT in vivo: a microdialysis study. J Neurochem 1993, 60(2):776-779.

107. Le Poul E, Laaris N, Doucet E, Laporte AM, Hamon M, Lanfumey L: Early desensitization of somato-dendritic 5-HT1A autoreceptors in rats treated with fluoxetine or paroxetine. Naunyn Schmiedebergs Arch Pharmacol 1995, 352:141-148.

108. Albert PR, Lembo P, Storring JM, Charest A, Saucier C: The 5-HT1A receptor: signaling, desensitization, and gene transcription. Neuropsychopharmacology 1996, 14:19-25.

109. Blier P, Pineyro G, el Mansari M, Bergeron R, de Montigny C: Role of somatodendritic 5-HT autoreceptors in modulating 5- $\mathrm{HT}$ neurotransmission. Ann N Y Acad Sci 1998, 861:204-216.

110. Berney A, Nishikawa M, Benkelfat C, Debonnel G, Gobbi G, Diksic M: An index of 5-HT synthesis changes during early antidepressant treatment: alpha-[(11)C]methyl-I-tryptophan PET study. Neurochem Int 2008, 52:701-708.

111. Hensler JG: Regulation of 5-HT1A receptor function in brain following agonist or antidepressant administration. Life Sci 2003, 72:1665-1682.

112. Riad M, Rbah L, Verdurand $M$, Aznavour N, Zimmer $L$, Descarries $L$ : Unchanged density of $5-\mathrm{HT}(1 \mathrm{~A})$ autoreceptors on the plasma membrane of nucleus raphe dorsalis neurons in rats chronically treated with fluoxetine. Neuroscience 2008, 151:692-700.

113. Moulin-Sallanon M, Charnay Y, Ginovart N, Perret P, Lanfumey L, Hamon M, Hen $R$, Fagret $D$, Ibanez $V$, Millet $P$ : Acute and chronic effects of citalopram on 5-HT1A receptor-labeling by [18F]MPPF and -coupling to receptors-G proteins. Synapse 2009, 63:106-116.

114. Yau JL, Olsson T, Noble J, Seckl JR: Serotonin receptor subtype gene expression in the hippocampus of aged rats following chronic amitriptyline treatment. Brain Res Mol Brain Res 1999, 70:282-287.

115. Cremers TI, Spoelstra EN, de Boer P, Bosker FJ, Mork A, den Boer JA, Westerink BH, Wikstrom HV: Desensitisation of 5-HT autoreceptors upon pharmacokinetically monitored chronic treatment with citalopram. Eur J Pharmacol 2000, 397:351-357.

116. Shen C, Li H, Meller E: Repeated treatment with antidepressants differentially alters 5-HT1A agonist-stimulated [35S]GTP gamma S binding in rat brain regions. Neuropharmacology 2002, 42:1031-1038.

117. Elena Castro M, Diaz A, del Olmo E, Pazos A: Chronic fluoxetine induces opposite changes in $\mathrm{G}$ protein coupling at pre and postsynaptic 5-HT1A receptors in rat brain. Neuropharmacology 2003, 44:93-101.

118. Mochizuki D, Hokonohara T, Kawasaki K, Miki N: Repeated administration of milnacipran induces rapid desensitization of somatodendritic 5-HT1A autoreceptors but not postsynaptic 5-HT1A receptors. J Psychopharmacol 2002, 16:253-260.

119. Cornelisse LN, van der Harst JE, Lodder JC, Baarendse PJ, Timmerman A, Mansvelder HD, Spruijt BM, Brussaard AB: Reduced 5-HT1A- and GABAB 
receptor function in dorsal raphe neurons upon chronic fluoxetine treatment of socially stressed rats. J Neurophysiol 2007, 78:196-204.

120. Casanovas JM, Vilaro MT, Mengod G, Artigas F: Differential regulation of somatodendritic serotonin 5-HT1A receptors by 2-week treatments with the selective agonists alnespirone (S-20499) and 8-hydroxy-2-(Di-npropylamino)tetralin: microdialysis and autoradiographic studies in rat brain. J Neurochem 1999, 72:262-272.

121. Welner SA, De Montigny C, Desroches J, Desjardins P, Suranyi-Cadotte BE: Autoradiographic quantification of serotonin $1 \mathrm{~A}$ receptors in rat brain following antidepressant drug treatment. Synapse 1989, 4:347-352.

122. Fanelli RJ, McMonagle-Strucko K: Alteration of 5-HT1A receptor binding sites following chronic treatment with ipsapirone measured by quantitative autoradiography. Synapse 1992, 12:75-81.

123. Le Poul E, Boni C, Hanoun N, Laporte AM, Laaris N, Chauveau J, Hamon M, Lanfumey L: Differential adaptation of brain 5-HT1A and 5-HT1B receptors and $5-\mathrm{HT}$ transporter in rats treated chronically with fluoxetine. Neuropharmacology 2000, 39:110-122.

124. Meltzer CC, Price JC, Mathis CA, Butters MA, Ziolko SK, Moses-Kolko E, Mazumdar S, Mulsant BH, Houck PR, Lopresti BJ, et al: Serotonin 1A receptor binding and treatment response in late-life depression. Neuropsychopharmacology 2004, 29:2258-2265.

125. Rabiner EA, Bhagwagar Z, Gunn RN, Cowen PJ, Grasby PM: Preferential 5HT(1A) Autoreceptor Occupancy by Pindolol is Attenuated in Depressed Patients: Effect of Treatment or an Endophenotype of Depression? Neuropsychopharmacology 2004, 29:1688-1698.

126. Penington NJ, Kelly JS: Serotonin receptor activation reduces calcium current in an acutely dissociated adult central neuron. Neuron 1990, 4:751-758

127. Li H, Waites CL, Staal RG, Dobryy Y, Park J, Sulzer DL, Edwards RH: Sorting of vesicular monoamine transporter 2 to the regulated secretory pathway confers the somatodendritic exocytosis of monoamines. Neuron 2005, 48:619-633.

128. Ford CP, Gantz SC, Phillips PE, Williams JT: Control of extracellular dopamine at dendrite and axon terminals. J Neurosci 2010, 30:6975-6983.

129. Kita JM, Kile BM, Parker LE, Wightman RM: In vivo measurement of somatodendritic release of dopamine in the ventral tegmental area. Synapse 2009, 63:951-960.

130. Lau T, Schneidt T, Heimann F, Gundelfinger ED, Schloss P: Somatodendritic serotonin release and re-uptake in mouse embryonic stem cell-derived serotonergic neurons. Neurochem Int 2010, 57:969-978.

131. Gross C, Zhuang X, Stark K, Ramboz S, Oosting R, Kirby L, Santarelli L, Beck $S$, Hen R: Serotonin1A receptor acts during development to establish normal anxiety-like behaviour in the adult. Nature 2002, 416:396-400.

132. Richardson-Jones JW, Craige CP, Guiard BP, Stephen A, Metzger KL, Kung HF, Gardier AM, Dranovsky A, David DJ, Beck SG, et al: 5-HT(1A) Autoreceptor Levels Determine Vulnerability to Stress and Response to Antidepressants. Neuron 2010, 65:40-52.

133. Nestler EJ, Gould E, Manji H, Buncan M, Duman RS, Greshenfeld HK, Hen R, Koester S, Lederhendler I, Meaney M, et al: Preclinical models: status of basic research in depression. Biol Psychiatry 2002, 52:503-528.

134. Hasler G, Drevets WC, Manji HK, Charney DS: Discovering Endophenotypes for Major Depression. Neuropsychopharmacology 2004, 29:1765-1781.

135. Cryan JF, Mombereau C: In search of a depressed mouse: utility of models for studying depression-related behavior in genetically modified mice. Mol Psychiatry 2004, 9:326-357.

136. Ramboz S, Oosting R, Amara DA, Kung HF, Blier P, Mendelsohn M, Mann JJ, Brunner D, Hen R: Serotonin receptor $1 A$ knockout: an animal model of anxiety-related disorder. Proc Natl Acad Sci USA 1998, 95:14476-14481.

137. Parks $C L$, Robinson PS, Sibille $E$, Shenk T, Toth M: Increased anxiety of mice lacking the serotonin1A receptor. Proc Natl Acad Sci USA 1998, 95:10734-10739.

138. Heisler LK, Chu HM, Brennan TJ, Danao JA, Bajwa P, Parsons LH, Tecott LH: Elevated anxiety and antidepressant-like responses in serotonin 5-HT1A receptor mutant mice. Proc Natl Acad Sci USA 1998, 95:15049-15054.

139. Santarelli L, Saxe M, Gross C, Surget A, Battaglia F, Dulawa S, Weisstaub N, Lee J, Duman R, Arancio O, et al: Requirement of hippocampal neurogenesis for the behavioral effects of antidepressants. Science 2003, 301:805-809

140. Kusserow H, Davies B, Hortnagl H, Voigt I, Stroh T, Bert B, Deng DR, Fink H, Veh RW, Theuring F: Reduced anxiety-related behaviour in transgenic mice overexpressing serotonin 1A receptors. Brain Res Mol Brain Res 2004, 129:104-116.

141. Lo lacono L, Gross C: Alpha-Ca2+/calmodulin-dependent protein kinase II contributes to the developmental programming of anxiety in serotonin receptor 1A knock-out mice. J Neurosci 2008, 28:6250-6257.

142. Albert PR, Francois BL: Modifying 5-HT1A Receptor Gene Expression as a New Target for Antidepressant Therapy. Front Neurosci 2010, 4:35.

143. Riad M, Watkins KC, Doucet E, Hamon M, Descarries L: Agonist-induced internalization of serotonin-1a receptors in the dorsal raphe nucleus (autoreceptors) but not hippocampus (heteroreceptors). J Neurosci 2001, 21:8378-8386.

144. Riad M, Zimmer L, Rbah L, Watkins KC, Hamon M, Descarries L: Acute treatment with the antidepressant fluoxetine internalizes 5-HT1A autoreceptors and reduces the in vivo binding of the PET radioligand [18F]MPPF in the nucleus raphe dorsalis of rat. J Neurosci 2004, 24:5420-5426.

145. Albert PR, Lemonde S: 5-HT1A Receptors, Gene Repression, and Depression: Guilt by Association. Neuroscientist 2004, 10:575-593.

146. Parks CL, Shenk T: The serotonin 1a receptor gene contains a TATA-less promoter that responds to MAZ and Sp1. J Biol Chem 1996, 271:4417-4430.

147. Charest A, Wainer BH, Albert PR: Cloning and differentiation-induced expression of a murine serotonin 1 A receptor in a septal cell line. J Neuroscience 1993, 13:5164-5171.

148. Czesak M, Lemonde S, Peterson EA, Rogaeva A, Albert PR: Cell-specific repressor or enhancer activities of Deaf-1 at a serotonin 1A receptor gene polymorphism. J Neurosci 2006, 26:1864-1871.

149. Fricker AD, Rios C, Devi LA, Gomes I: Serotonin receptor activation leads to neurite outgrowth and neuronal survival. Brain Res Mol Brain Res 2005, 138:228-235.

150. Cowen DS, Molinoff PB, Manning DR: 5-hydroxytryptamine1A receptormediated increases in receptor expression and activation of nuclear factor-kappaB in transfected Chinese hamster ovary cells. Mol Pharmacol 1997, 52:221-226.

151. Abdouh M, Albert PR, Drobetsky E, Filep JG, Kouassi E: 5-HT1A-mediated promotion of mitogen-activated $T$ and $B$ cell survival and proliferation is associated with increased translocation of NF-kappaB to the nucleus. Brain Behav Immun 2004, 18:24-34.

152. Abdouh M, Storring JM, Riad M, Paquette Y, Albert PR, Drobetsky E, Kouassi E: Transcriptional mechanisms for induction of 5-HT1A receptor mRNA and protein in activated B and T lymphocytes. J Biol Chem 2001, 276:4382-4388.

153. Iken K, Chheng S, Fargin A, Goulet AC, Kouassi E: Serotonin upregulates mitogen-stimulated B lymphocyte proliferation through 5-HT1A receptors. Cell Immunol 1995, 163:1-9.

154. Meijer OC, Williamson A, Dallman MF, Pearce D: Transcriptional repression of the 5-HT1A receptor promoter by corticosterone via mineralocorticoid receptors depends on the cellular context. J Neuroendocrinol 2000, 12:245-254.

155. Lemonde S, Rogaeva A, Albert PR: Cell type-dependent recruitment of trichostatin A-sensitive repression of the human 5 -HT1A receptor gene. $J$ Neurochem 2004, 88:857-868.

156. Ou XM, Jafar-Nejad H, Storring JM, Meng JH, Lemonde S, Albert PR: Novel dual repressor elements for neuronal cell-specific transcription of the rat 5-HT1A receptor gene. J Biol Chem 2000, 275:8161-8168.

157. Schoenherr CJ, Anderson DJ: Silencing is golden: negative regulation in the control of neuronal gene transcription. Curr Opin Neurobiol 1995, 5:566-571.

158. Jones FS, Meech R: Knockout of REST/NRSF shows that the protein is a potent repressor of neuronally expressed genes in non-neural tissues. BioEssays 1999, 21:372-376.

159. Chen ZF, Paquette AJ, Anderson DJ: NRSF/REST is required in vivo for repression of multiple neuronal target genes during embryogenesis [see comments]. Nat Genet 1998, 20:136-142.

160. Ou XM, Lemonde S, Jafar-Nejad H, Bown CD, Goto A, Rogaeva A, Albert PR: Freud-1: A novel calcium-regulated repressor of the 5-HT1A receptor gene. J Neuroscience 2003, 23:7415-7425.

161. Hadjighassem MR, Austin MC, Szewczyk B, Daigle M, Stockmeier CA, Albert PR: Human Freud-2/CC2D1B: a novel repressor of postsynaptic serotonin-1A receptor expression. Biol Psychiatry 2009, 66:214-222 
162. Hadjighassem MR, Galaraga K, Albert PR: Freud-2/CC2D1B mediates dual repression of the serotonin-1A receptor gene. Eur J Neurosci 2011, 33:214-223.

163. Szewczyk B, Albert PR, Rogaeva A, Fitzgibbon H, May WL, Rajkowska G, Miguel-Hidalgo JJ, Stockmeier CA, Woolverton WL, Kyle PB, et al: Decreased expression of Freud-1/CC2D1A, a transcriptional repressor of the 5-HT1A receptor, in the prefrontal cortex of subjects with major depression. Int J Neuropsychopharmacol 2010, 13:1089-1101.

164. Goswami DB, May WL, Stockmeier CA, Austin MC: Transcriptional expression of serotonergic regulators in laser-captured microdissected dorsal raphe neurons of subjects with major depressive disorder: sexspecific differences. J Neurochem 2010, 112:397-409.

165. Ou XM, Storring JM, Kushwaha N, Albert PR: Heterodimerization of mineralocorticoid and glucocorticoid receptors at a novel negative response element of the 5-HT1A receptor gene. J Biol Chem 2001, 276:14299-14307.

166. Meijer OC, de Kloet ER: Corticosterone and serotonergic neurotransmission in the hippocampus: functional implications of central corticosteroid receptor diversity. Crit Rev Neurobiol 1998, 12:1-20.

167. Neumaier JF, Sexton TJ, Hamblin MW, Beck SG: Corticosteroids regulate 5$\mathrm{HT}(1 \mathrm{~A})$ but not 5-HT(1B) receptor mRNA in rat hippocampus. Brain Res Mol Brain Res 2000, 82:65-73.

168. Laaris N, Haj DS, Hamon M, Lanfumey L: Glucocorticoid receptor-mediated inhibition by corticosterone of 5-HT1A autoreceptor functioning in the rat dorsal raphe nucleus. Neuropharmacology 1995, 34:1201-1210.

169. Fairchild G, Leitch MM, Ingram CD: Acute and chronic effects of corticosterone on 5-HT1A receptor-mediated autoinhibition in the rat dorsal raphe nucleus. Neuropharmacology 2003, 45:925-934.

170. Hensler JG, Advani T, Monteggia LM: Regulation of serotonin-1A receptor function in inducible brain-derived neurotrophic facto knockout mice after administration of corticosterone. Biol Psychiatry 2007, 62:521-529.

171. Lanzenberger R, Wadsak W, Spindelegger C, Mitterhauser M, Akimova E, Mien LK, Fink M, Moser U, Savli M, Kranz GS, et al: Cortisol plasma levels in social anxiety disorder patients correlate with serotonin-1A receptor binding in limbic brain regions. Int J Neuropsychopharmacol 2010, 13:1129-1143.

172. Hery M, Semont A, Fache MP, Faudon M, Hery F: The effects of serotonin on glucocorticoid receptor binding in rat raphe nuclei and hippocampal cells in culture. J Neurochem 2000, 74:406-413.

173. Froger N, Palazzo E, Boni C, Hanoun N, Saurini F, Joubert C, DutriezCasteloot I, Enache M, Maccari S, Barden N, et al: Neurochemical and behavioral alterations in glucocorticoid receptor-impaired transgenic mice after chronic mild stress. J Neurosci 2004, 24:2787-2796.

174. Le François B, Czesak M, Steubl D, Albert PR: Transcriptional regulation at a HTR1A polymorphism associated with mental illness. Neuropharmacology 2008, 55:977-985.

175. Lemonde S, Turecki G, Bakish D, Du L, Hrdina PD, Bown CD, Sequeira A, Kushwaha N, Morris SJ, Basak A, et al: Impaired repression at a 5 hydroxytryptamine $1 \mathrm{~A}$ receptor gene polymorphism associated with major depression and suicide. J Neuroscience 2003, 23:8788-8799.

176. Huggenvik Jl, Michelson RJ, Collard MW, Ziemba AJ, Gurley P, Mowen KA: Characterization of a nuclear deformed epidermal autoregulatory factor1 (DEAF-1)-related (NUDR) transcriptional regulator protein. $\mathrm{Mol}$ Endocrinol 1998, 12:1619-1639.

177. Michelson RJ, Collard MW, Ziemba AJ, Persinger J, Bartholomew B, Huggenvik J: Nuclear DEAF-1-related (NUDR) protein contains a novel DNA binding domain and represses transcription of the heterogeneous nuclear ribonucleoprotein A2/B1 promoter. J Biol Chem 1999, 274:30510-30519.

178. Szewczyk B, Albert PR, Burns AM, Czesak M, Overholser JC, Jurjus GJ, Meltzer HY, Konick LC, Dieter L, Herbst N, et al: Gender-specific decrease in NUDR and 5-HT1A receptor proteins in the prefrontal cortex of subjects with major depressive disorder. Int I Neuropsychopharmacol 2009, 12:155-168.

179. Parsey RV, Oquendo MA, Ogden RT, Olvet DM, Simpson N, Huang YY, Van Heertum RL, Arango V, Mann Jj: Altered serotonin $1 \mathrm{~A}$ binding in majo depression: a [carbonyl-C-11]WAY100635 positron emission tomography study. Biol Psychiatry 2006, 59:106-113.

180. Sullivan GM, Ogden RT, Oquendo MA, Kumar JS, Simpson N, Huang YY, Mann JJ, Parsey RV: Positron emission tomography quantification of
serotonin-1A receptor binding in medication-free bipolar depression. Biol Psychiatry 2009, 66:223-230.

181. Parsey RV, Ogden RT, Miller JM, Tin A, Hesselgrave N, Goldstein E, Mikhno A, Milak M, Zanderigo F, Sullivan GM, et al: Higher Serotonin 1A Binding in a Second Major Depression Cohort: Modeling and Reference Region Considerations. Biol Psychiatry 2010, 68:170-178.

182. Kageyama R, Ohtsuka T, Hatakeyama J, Ohsawa R: Roles of bHLH genes in neural stem cell differentiation. Exp Cell Res 2005, 306:343-348.

183. Jacobsen $K X$, Vanderluit J, Slack RS, Albert PR: HES1 regulates 5-HT1A receptor gene transcription at a functional polymorphism: Essential role in developmental expression. Mol Cell Neurosci 2008, 38:349-358.

184. Iyo AH, Kieran N, Chandran A, Albert PR, Wicks I, Bissette G, Austin MC: Differential regulation of the serotonin $1 \mathrm{~A}$ transcriptional modulators five prime repressor element under dual repression-1 and nucleardeformed epidermal autoregulatory factor by chronic stress. Neuroscience 2009, 163:1119-1127

185. Hendricks T, Francis N, Fyodorov D, Deneris ES: The ETS domain factor Pet- 1 is an early and precise marker of central serotonin neurons and interacts with a conserved element in serotonergic genes. J Neurosci 1999, 19:10348-10356.

186. Hendricks TJ, Fyodorov DV, Wegman LJ, Lelutiu NB, Pehek EA, Yamamoto B, Silver J, Weeber EJ, Sweatt JD, Deneris ES: Pet-1 ETS gene plays a critical role in 5-HT neuron development and is required for normal anxiety-like and aggressive behavior. Neuron 2003, 37:233-247.

187. Jacobsen KX, Czesak M, Deria M, Le Francois B, Albert PR: Region-specific regulation of 5-HT1A receptor expression by Pet-1-dependent mechanisms in vivo. J Neurochem 2011, 116:1066-1076.

188. Liu C, Maejima T, Wyler SC, Casadesus G, Herlitze S, Deneris ES: Pet-1 is required across different stages of life to regulate serotonergic function. Nat Neurosci 2010, 13:1190-1198.

189. Yadav PN, Abbas Al, Farrell MS, Setola V, Sciaky N, Huang XP, Kroeze WK, Crawford LK, Piel DA, Keiser MJ, et al: The Presynaptic Component of the Serotonergic System is Required for Clozapine's Efficacy. Neuropsychopharmacology 2011, 36:638-651.

190. Kishi T, Tsunoka T, Ikeda M, Kawashima K, Okochi T, Kitajima T, Kinoshita Y, Okumura T, Yamanouchi $Y$, Inada $T$, et al: Serotonin $1 \mathrm{~A}$ receptor gene and major depressive disorder: an association study and meta-analysis. J Hum Genet 2009, 54:629-633.

191. Anttila S, Huuhka K, Huuhka M, Rontu R, Hurme M, Leinonen E, Lehtimaki T: Interaction between 5-HT1A and BDNF genotypes increases the risk of treatment-resistant depression. J Neural Transm 2007, 114:1065-1068.

192. Kraus MR, Al-Taie O, Schafer A, Pfersdorff M, Lesch KP, Scheurlen M: Serotonin-1A receptor gene HTR1A variation predicts interferon-induced depression in chronic hepatitis C. Gastroenterology 2007, 132:1279-1286.

193. Neff CD, Abkevich V, Packer JC, Chen Y, Potter J, Riley R, Davenport C, DeGrado Warren J, Jammulapati S, Bhathena A, et al: Evidence for HTR1A and LHPP as interacting genetic risk factors in major depression. $\mathrm{Mol}$ Psychiatry 2009, 14:621-630.

194. Zetzsche T, Preuss UW, Bondy B, Frodl T, Zill P, Schmitt G, Koutsouleris N, Rujescu D, Born C, Reiser M, et al: 5-HT1A receptor gene C -1019 G polymorphism and amygdala volume in borderline personality disorder. Genes Brain Behav 2008, 7:306-313.

195. Lenze EJ, Shardell M, Ferrell RE, Orwig D, Yu-Yahiro J, Hawkes W, Fredman L, Miller R, Magaziner J: Association of serotonin-1A and 2A receptor promoter polymorphisms with depressive symptoms and functional recovery in elderly persons after hip fracture. $J$ Affect Disord 2008.

196. Wu Y, Xu Y, Sun Y, Wang YF, Li X, Lang XE, Wang WP, Zhang KR: Association between the serotonin $1 \mathrm{~A}$ receptor $\mathrm{C}(-1019) \mathrm{G}$ polymorphism and major depressive disorder in the northern Han ethnic group in China. Chin Med J (Engl) 2008, 121:874-876.

197. Zhang K, Xu Q, Xu Y, Yang H, Luo J, Sun Y, Sun N, Wang S, Shen Y: The combined effects of the 5-HTTLPR and 5-HTR1A genes modulates the relationship between negative life events and major depressive disorder in a Chinese population. J Affect Disord 2009, 114:224-231.

198. Hettema JM, An SS, van den Oord EJ, Neale MC, Kendler KS, Chen X: Association study between the serotonin $1 A$ receptor (HTR1A) gene and neuroticism, major depression, and anxiety disorders. Am J Med Genet B Neuropsychiatr Genet 2008, 147B:661-666.

199. Domschke K, Braun M, Ohrmann P, Suslow T, Kugel H, Bauer J, Hohoff C, Kersting A, Engelien A, Arolt $V$, et al: Association of the functional -1019C/ 
G 5-HT1A polymorphism with prefrontal cortex and amygdala activation measured with $3 \mathrm{~T} \mathrm{fMRI}$ in panic disorder. Int I Neuropsychopharmacol 2006, 9:349-355.

200. Fakra E, Hyde LW, Gorka A, Fisher PM, Munoz KE, Kimak M, Halder I, Ferrell RE, Manuck SB, Hariri AR: Effects of HTR1A C(-1019)G on amygdala reactivity and trait anxiety. Arch Gen Psychiatry 2009, 66:33-40.

201. Rothe C, Gutknecht L, Freitag C, Tauber R, Mossner R, Franke P, Fritze J, Wagner G, Peikert G, Wenda B, et al: Association of a functional 1019CG 5-HT1A receptor gene polymorphism with panic disorder with agoraphobia. Int J Neuropsychopharmacol 2004, 7:189-192.

202. Choi WS, Lee BH, Yang JC, Kim YK: Association Study between 5-HT1A Receptor Gene C(-1019)G Polymorphism and Panic Disorder in a Korean Population. Psychiatry Investig 2010, 7:141-146.

203. Chipman P, Jorm AF, Tan XY, Easteal S: No association between the serotonin-1A receptor gene single nucleotide polymorphism rs6295C/G and symptoms of anxiety or depression, and no interaction between the polymorphism and environmental stressors of childhood anxiety or recent stressful life events on anxiety or depression. Psychiatr Genet 2010, 20:8-13.

204. David SP, Murthy NV, Rabiner EA, Munafo MR, Johnstone EC, Jacob R, Walton RT, Grasby PM: A functional genetic variation of the serotonin (5$\mathrm{HT}$ ) transporter affects 5-HT1A receptor binding in humans. J Neurosci 2005, 25:2586-2590.

205. Mann JJ, Brent DA, Arango V: The neurobiology and genetics of suicide and attempted suicide: a focus on the serotonergic system. Neuropsychopharmacology 2001, 24:467-477.

206. Stockmeier CA: Involvement of serotonin in depression: evidence from postmortem and imaging studies of serotonin receptors and the serotonin transporter. J Psychiatr Res 2003, 37:357-373.

207. Cremers TI, Wiersma LJ, Bosker FJ, den Boer JA, Westerink BH, Wikstrom HV: Is the beneficial antidepressant effect of coadministration of pindolol really due to somatodendritic autoreceptor antagonism? Biol Psychiatry 2001, 50:13-21.

208. Arborelius L, Linner L, Wallsten C, Ahlenius S, Svensson TH: Partial 5-HT1A receptor agonist properties of (-)pindolol in combination with citalopram on serotonergic dorsal raphe cell firing in vivo. Psychopharmacology (Berl) 2000, 151:77-84.

209. Haddjeri N, de Montigny C, Blier P: Modulation of the firing activity of rat serotonin and noradrenaline neurons by (+/-)pindolol. Biol Psychiatry 1999, 45:1163-1169.

210. Martinez D, Hwang D, Mawlawi O, Slifstein M, Kent J, Simpson N, Parsey RV, Hashimoto T, Huang Y, Shinn A, et al: Differential occupancy of somatodendritic and postsynaptic $5 \mathrm{HT}(1 \mathrm{~A})$ receptors by pindolol: a dose-occupancy study with [11C]WAY 100635 and positron emission tomography in humans. Neuropsychopharmacology 2001, 24:209-229.

211. Serrats J, Artigas F, Mengod G, Cortes R: An autoradiographic study of the influence of pindolol upon [35S]GTPgammaS binding in rat, guinea pig and human brain. Int I Neuropsychopharmacol 2004, 7:27-34.

212. Lemonde S, Du L, Bakish D, Hrdina P, Albert PR: Association of the C (-1019)G 5-HT1A functional promoter polymorphism with antidepressant response. Int J Neuropsychopharmacol 2004, 7:501-506.

213. Kato M, Fukuda T, Wakeno M, Okugawa G, Takekita Y, Watanabe S, Yamashita M, Hosoi Y, Azuma J, Kinoshita T, Serretti A: Effect of 5-HT1A gene polymorphisms on antidepressant response in major depressive disorder. Am J Med Genet B Neuropsychiatr Genet 2009, 150B:115-123.

214. Yevtushenko OO, Oros MM, Reynolds GP: Early response to selective serotonin reuptake inhibitors in panic disorder is associated with a functional 5-HT1A receptor gene polymorphism. J Affect Disord 2010, 123:308-311.

215. Hahn A, Lanzenberger R, Wadsak W, Spindelegger C, Moser U, Mien LK, Mitterhauser M, Kasper S: Escitalopram enhances the association of serotonin-1A autoreceptors to heteroreceptors in anxiety disorders. J Neurosci 2010, 30:14482-14489.

doi:10.1186/1756-6606-4-21

Cite this article as: Albert et al: Transcriptional dysregulation of 5-HT1A autoreceptors in mental illness. Molecular Brain 2011 4:21.

\section{Submit your next manuscript to BioMed Central and take full advantage of:}

- Convenient online submission

- Thorough peer review

- No space constraints or color figure charges

- Immediate publication on acceptance

- Inclusion in PubMed, CAS, Scopus and Google Scholar

- Research which is freely available for redistribution 